\title{
Structural pattern and tectonic division of Qaidam basin and adjacent area, NW China
}

\author{
Xiaohu Zhou ${ }^{1,2, \text { a }}$ \\ ${ }^{1}$ Department of Geology, Northwest University/State Key Laboratory of Continental Dynamics, \\ Xi'an, 710069, China \\ ${ }^{2}$ Shaanxi Key Laboratory of Exploration And Comprehensive Utilization of Mineral Resources, \\ Xi'an 710054,China
}

a274897586@qq.com

\begin{abstract}
Keywords: Structural geology, tectonic, Qaidam basin, Orogenic belt
\end{abstract}
Abstract. Central orogenic belt means sandwiched between Tarim block, North China block and Yangtze block, it was EW distributed by Kunlun-Qilian-Qinling-Dabie-Sulu mountain chain and sandwiched between Lot composition, stretching more than 4,000 kilometers of Phanerozoic orogenic complex system. Qaidam Basin is located in the middle of the central orogenic belt just south of the Kunlun-Qinling orogenic belt, north of Qilian orogenic belt, north west across the Altyn fault and adjacent Tarim Basin, is the central link of connected orogenic belt in China Continental geology occupy an important position. Faults is passed tectonic evolution of the lithosphere, the deep dynamic processes and material composition information of the most important tectonic window, therefore, since the 1960s the international Geodynamics plans have been undertaken on the mantle plan, and continental lithosphere dynamics Program faults regarded as one of the important research, particularly in the implementation of continental dynamics program today, faults clarify crustal evolution in order to become the continent, continental dynamics model established core research content. Qin Qi Kun faults are well developed, the main fault controls the structural and stratigraphic division. Based on comprehensive geological, geophysical, spatial and temporal distribution of data analyzed in the study area and different kinetic principal stress field on the main fault zone and tectonic features for a more systematic summary and classification for the future in other areas research laid a good foundation.

\section{Introduction}

Orogen crust is relatively stable in some areas and proposed early comprises two processes, namely the scope of rock deformation within orogenic belt and the mountains formation in the later use, orogeny includes forming the upper mountains, overthrust, fold fracture and other processes, as well as plastic folds deep, metamorphism and magmatism. Since the 1980s, the theory of plate tectonics was constructed oceanic subduction, arc-arc collision, land-arc collision and continent-continent collision orogeny orogenic belt will shift from the early "to groove orogenic belt" to "plate orogenic with "people composed of orogenic belts, the evolution of complexity and increasing depth understanding of regularity, fundamentally changed the previously considered orogenic belt is trough return understanding. According to the theory of plate tectonics, the orogenic belts classified as subduction, obduction type, collision type and intracontinental type, with seismic tomography, high-temperature high-pressure test, geochronology and geochemical techniques and disciplines The continuous development of related orogenic belt structure, deformation and metamorphism, orogenic time, deep action and a deeper understanding of dynamics, late block tectonics has been unable to explain the exact role of Continental Dynamics Strip 1980s, the international succession that "Lithosphere Program" and "continental dynamics program."

On the basis of the tectonic units, some scholars have proposed tectonic phase is an essential part of the orogenic belt, Ahlemann, Celtic and Leiter proposed tectonic phase of the orogenic process and Plate interaction between direct link. Tectonic phase can be divided into six categories: obduction substrate similar, mixed with class, foreland fold and thrust similar, the main shear similar, magmatic arc similar, grind pull similar stone basin, this tectonic facies distribution patterns in different 
combinations in different types of orogenic belt. In addition, according to the four basic structural environment that is discrete, convergence, collision and slip is to separate the 29 kinds of tectonic phase.

\section{Geological setting}

Central orogenic belt means sandwiched between plots of Tarim, North China block and Yangtze block, it was something-EW distributed by Kunlun-Qilian-Qinling-Dabie-Sulu mountain chain and sandwiched between Lot composition, stretching more than 4,000 kilometers of Phanerozoic orogenic complex system (Fig.1). Qaidam Basin is located in the middle of the central orogenic belt just south of the Kunlun-Qinling orogenic belt, north of Qilian orogenic belt, north west across the Altyn fault and adjacent Tarim Basin, is the central link of things connected orogenic belt in China Continental geology occupy an important position.

Paleomagnetic studies showed that the study area is located in Altun-Qilian-Kunlun around the body put together, proliferation and Tethys basin and the Indian Ocean, the opening and closing of the last open a close relationship. Qaidam Basin around the periphery of the body with the typical "multi ocean basin, more body, more arc" feature and "multi-dive, more collisions, more orogeny" dynamic process.

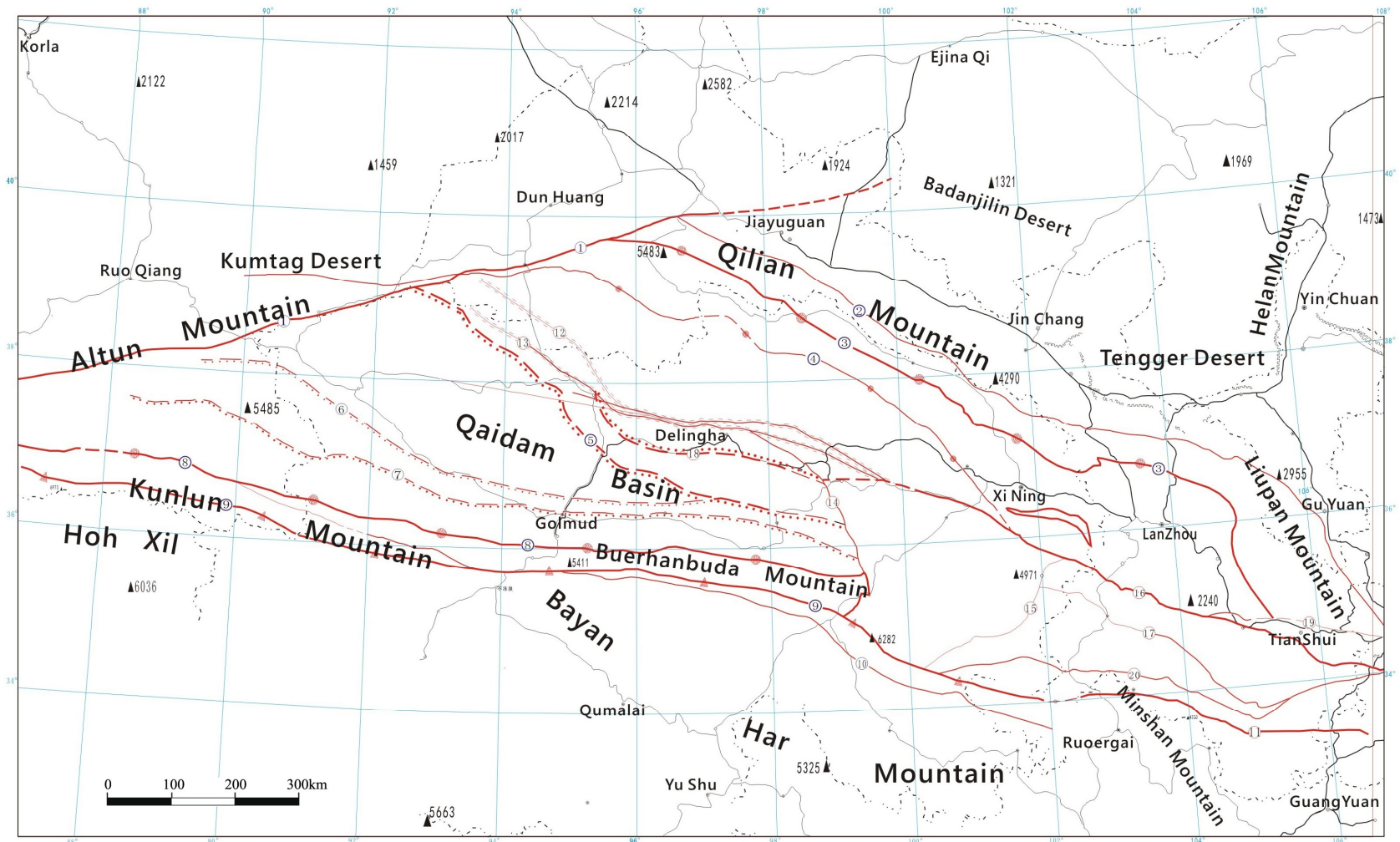

Fig.1 Structural and faults distribution map of Qaidam basin and adjacent area

Qilian terrane, northern margin of the Qaidam Qaidam-East Kunlun terrane similar metamorphic basement and the Yangtze, developed in 900-1000Ma the Rodinia supercontinent, Followed by the common experience of 700- 800Ma supercontinent cleavage, and superimposed 396-567Ma (Sm-Nd and $\mathrm{Rb}-\mathrm{Sr}$ method) metamorphic event, so that the older metamorphic basement reactivation and the involvement of early Paleozoic tectonic movement.

The current study suggests that the evolution of the tectonic framework of the Qaidam Basin is changing over time, with multiple tectonic evolution history, its development process is phased, have at different stages of development to history different tectonic regime, basin and the periphery of the Early Paleozoic in multiple sectors put together, hyperplasia, collision orogeny is characterized by late Paleozoic, Mesozoic and Cenozoic to inland stretch, depression and orogenic inner panel characterized this evolution process control different periods deposition the formation and evolution of the basin. 
Paleozoic rocks in the study area is formed in marine sediments as the main line, and in the development of the new generation of terrestrial sedimentary rock series is characterized, and experience more of tectonic deformation transformation. Jurassic ago, this area experienced a Cambrian-Ordovician-Early Silurian formation and development of the world Qin Qi Kun Yang and Early-Middle Silurian oceanic basin closure collision orogenic stage, Late Devonian-Carboniferous Southern Kunlun ocean development (Paleotethyan) formation and trench-arc basin system and in the closing stages of the Late Permian, the Qaidam Basin Precambrian to Permian experienced Paleozoic oceanic-island arc-back arc basin tectonic evolution stage system. By region ophiolite, UHP metamorphic rock geochemistry and SHRIMP dating research shows that the development of the northern margin of the Qaidam Basin has UHP metamorphic belt, gneiss zircon Coesite proved to be a typical continental subduction. The study shows that the region is not only a typical mountain-basin binding domain structure, but also experienced a complex, multi-phase structure evolution.

\section{Tectonic division of Qaidam basin and adjacent areas}

Qaidam Basin, with a long-term active edge of ancient Eurasia, Presinian to land reclamation movement-based Cambrian-Ordovician and Late Carboniferous-Triassic taphrogeny active, Silurian-Mud Ji basin and Jurassic-Cretaceous to orogeny based, since the new generation, to thrust nappe inland and strong uplift based. The main structure layer of Luliang, Jinningian, Caledonian, Indosinian, Yanshan and Himalayan, etc. 6.

(1) Luliang tectonic layer

Luliang Major thermal event, so that the ancient Proterozoic mobile belts consolidation, deformation, formation of early continental crust, Luliang large range of geological events spread west Tarim, north of Dunhuang, in Qilian, east to the Hualong, Oliver and other places. Paleoproterozoic late thermal event showed activity type deposition of approximately Jinshuikou rock group, darken large slate group suffered widespread regional dynamic heat metamorphism, formed from the high greenschist facies-low-high amphibolite facies amphibolite facies multiphase deterioration, and progressive metamorphic belt. Mixing rock, metamorphic rocks mixed granite and senior companions appear. Luliang section of the structure between the Qilian Mountains in the eastern end of the contact has a relatively clear relationship, the Great Wall Group Department millstone ditch parallel quartz sandstone unconformably overlies the Paleoproterozoic, overburden Changcheng System is a single-phase metamorphism (lower greenschist facies quartz sandstone construction), in Altun also see a Middle Proterozoic unconformity above darken large slate base.

(2) Jinningian tectonic

In Qingshuiquan, Wu and other places are distributed properly, the Neoproterozoic ophiolite, indicates that during this period the presence of ocean basin, activity type deposited Wanbaogou group, tensile depths of mafic magma eruption, pillow structure development, the formation of a bit more alkaline ocean island basalts, this ocean basin in Neoproterozoic northward subduction, under inserted, in the East Kunlun Mountains form the northern slope of the island arc, and the emergence of Neoproterozoic granite. North Qaidam Paleoproterozoic darken Osaka Group and Quanji group Mahuanggou group angular unconformity, and the other in the middle of Altun also see a Sinian Quanji Group unconformably overlies the Jixian, so before Sinian fold degenerate.

Jinningian geological events only makes wood tower blocks south and the Yangtze plate, north of Qilian and Alashan a split plate together to form a stable platform area in western China-the Western sector, but also due to the subduction orogeny, East Kunlun suture belt north of the trench (pots)-arc (magmatic arc)-prototype basin (cap deposition) system is the beginning. The effect of the structure to make the Neoproterozoic strata constitute folded basement.

(3) Caledonian tectonic

Caledonian orogeny is a strong event. East Kunlun ocean basin, the northern Qaidam basin and the North Qilian ocean oceanic basins reduction, subduction, collision orogeny, Upper Devonian universal coverage with angular unconformity on the lower Paleozoic strata. "Qinghai, Gansu Regional 
Geology" in the movement, also known as Sabina, refers to the angle Laojunshan Late Devonian and Early Paleozoic metamorphic conglomerate clastic system Hanxia unconformity between groups, the motion occurs in the Late Silurian and the world, between the early Devonian mud, also performed extensive in South Qilian this movement and strong, Late Devonian-Early Carboniferous strata unconformably on the Silurian, mud on the periphery of the Qaidam Basin Lower Carboniferous basin unified universal with angular unconformity on the lower Paleozoic sedimentary or older formations, such as the lime ditch and Auron Mountain Brook yak group unconformity on Shihuigou group, Hills in the ditch between the beach and the United Yak mountain Group unconformity. North Queensland in the south to the north Qilian fault, are involved in the Caledonian orogeny. This issue features a two-way collision subduction squeeze epeirogenic, orogeny, subduction zone north of Qilian, east Kunlun south northward subduction zones, in the north of the northern Qaidam subduction zone. The orogenic events of the northern Qinghai continent fused to form Qilian and Qaidam block, so that the original Tethys disappeared.

(3) Indosinian tectonic

Indosinian North Tethys basin subduction occurs on both sides, north of Kunlun fault, south of Jinsha River-Yushu-Xijir Ulan Lake fault, the fault is in North Queensland and South China plate plate collision suture early Indosinian band. In the early Indosinian pull Hubei section of Eastern Kunlun Mountains, Dulan Triassic Hubei pull Hills angular unconformity overlying the Triassic Laguna bank group or older strata, Bayan gol area, Kunlun fault zone on the south side Shannan slope angle Triassic Babaoshan Group unconformably overlies the Triassic downtown warehouse ditch between groups, Longwuhe group, Gulang embankment, east of the pond Oliver Group by extrusion, deformation, orogeny, formed early Indosinian Orogen. Late Triassic Tethys basin along the Jinsha River-Yushu suture beneath the Qiangtang dive, Bayan Har fold uplift, become late Indosinian belt, continental Jurassic sporadically distributed In the tape.

Indosinian tectonic event ended the Qaidam basin uplift and erosion of long-term history, began to accept the Cenozoic deposits from local to large.

(4) Yanshan tectonic

Early Yanshanian tectonic movement occurred in the late Jurassic, ancient climatic conditions drying climate change become oxidized, Qiangtang area north and basically completed the transition from sea to land a huge, which Bangong-Nujiang Jurassic ocean basin fully closed and the final collision Gangdese block and Qiangtang blocks related. In Tongren County, North, North Delhi, mirror iron Shandong, in Qilian other underground Cretaceous and lower strata are unconformably overlying contact with overlying older strata, in Lulehe, fish cards, Dome Hill, Dameigou other places mainly for parallel unconformity. Late Yanshanian tectonic event occurred in the late Cretaceous period of Qaidam Basin, with block-based activities, generally eroded Mesozoic.

(5) Himalayan tectonic

Indian plate under the Eurasian plate to the subduction from south to north, after a huge arc effect, along with the northern part of Qinghai-Tibet Plateau uplift, forming a large stack of Qaidam Basin on the composite basin. Since ancient times, there are three acts in the basin since the Eocene tectonic movements, is particularly strong and impressive new performance Quaternary tectonic movement, resulting in a series of major geological events, performance paleo-Kunlun mountain, Altun, Zong Service Long Mountain Rise and uplifting, there are extruded with twist-pressure two forms, the terrain has four planation from the basin to the mountains, piedmont and development has a huge alluvial fan, modern mountains gradually formed. With the mountain uplift and subsidence of the basin, basin-mountain junction development and the occurrence of strong overthrust nappe, such as the northern Qaidam Saishiteng Piedmont, xitiesan Piedmont, the southern edge of the wood Qimantage Piedmont, old Formation thrust over the Quaternary. Nalinggele River, Golmud River due to the uplift of East Kunlun Mountains, rivers continue south capture, collapsed over three rows of the watershed, upstream to Dakun Nan fault, Kunlun Mountains continue to uplift lead to Pleistocene-Holocene alluvial fan then advance to the basin. Tertiary basin folds generally box-like or comb-like, dome-shaped, nose, etc., early in the Pleistocene have weak deformation. 


\section{Conclusions}

Faults is passed tectonic evolution of the lithosphere, the deep dynamic processes and material composition information of the most important tectonic window, therefore, since the 1960s the international Geodynamics plans have been undertaken on the mantle plan, plan and continental lithosphere dynamics Program faults regarded as one of the important research, particularly in the implementation of continental dynamics program today, faults clarify crustal evolution in order to become the continent, continental dynamics model established core research content. Qin Qi Kun faults are well developed, the main fault (with) the structural and stratigraphic controls division. Based on comprehensive geological, geophysical, spatial and temporal distribution of data analyzed in the study area and different Kinetic principal stress field on the main fault zone and tectonic features for a more systematic summary and classification for the future in other areas research laid a good foundation.

\section{Acknowledgements}

This work was financially supported by the Natural Science Foundation of Shaanxi Province (2013JM5008), Opening Foundation of Shaanxi Key Laboratory of Exploration And Comprehensive Utilization of Mineral resources(2015KC001) and Northwestern University Teaching Research Projects(JX13029)..

\section{References}

[1] Ashwal L D, Tucker R D and Zinner E K. Geochim. Acta, Vol. 63(18)(1999), p. 2839-2851

[2] Barbarin B. Lithos. Vol. 46(1999), p. 605-626

[3] Bian Q T, Li D H, Pospelov I, et al. Journal of Asian Earth Sciences, Vol. 23(2004), p. 577-596

[4] Collins W J, Beams S D, White A J R and Chappell B W. Contr. Mineral. Petrol. Vol. 10(1982), p. 189-200

[5] Decelles P G, Currie B S. Geology, Vol. 24(7)(1996), p. 591-594

[6] Evans J R, Zucca J J..J. Geophys. Res., Vol. 93(1988), p. 15016-15036

[7] Halls H C. Geo science Canada, Vol. 9(3)(1982), p. 145-154

[8] Li Z X, Zhang L H and Powell C M. Austrnlia Earth Science, Vol. 43(6)(1996), p. 593-604

[9] Maruyama S, Liou J G and Terabayashi M. International Geology Review, Vol. 38(1996), p. 485-594

[10] Meschede M.. Chem Geol, Vol. 56(1986), p. 207-218

[11] Mattinson C G, Wooden J L, Liou J G, et al. Mineralogy and Petrology, Vol. 88(2006), p. 227-241

[12] Le Roex A.P.and Dick, H.J.B. J.Petrol., Vol. 24(1983), p. 267-318

[13] Gao S, Liu X M, Yuan H L. Geostand Newsl, Vol. 26(2)(2002), p. 181-195 